\title{
Estudio crítico de la representación del estado de la pobreza en la televisión
}

\author{
A critical study of the representation of poverty on TV \\ JuAn CARlos Gil-GonzÁlez \\ Departamento de Periodismo I. Universidad de Sevilla. \\ jcgil@us.es \\ Fernando Ramón Contreras-Medina \\ Departamento de Periodismo I. Universidad de Sevilla. \\ fmedina@us.es
}

Recibido: 2 de julio de 2013

Aprobado: 11 de abril de 2014

\section{Resumen}

Este texto ofrece un estudio innovador de la representación mediática de la situación de pobreza de las personas en los medios de comunicación masivamente consumidos. En este estudio visual, que compara similitudes entre la pintura barroca y las cualidades neobarrocas que ofrece la televisión en la cultura de masa, pretende ver similitudes y diferencias y observar cómo existen unos parámetros culturales que sobre el concepto de pobreza se ha asentado en el ideario colectivo. Además, se analiza la creación mediática de la marginación social y su interpretación en el entramado de la cultura popular. Palabras clave: televisión, filosofía de la comunicación, pobreza, cultura popular.

Gil-González, J.C., Contreras-Medina, F.R. (2014): Estudio crítico de la representación del estado de la pobreza en la televisión. Arte, Individuo y Sociedad, 26(3) 437-451

\begin{abstract}
This article offers an innovative research of the mediatic representation of poverty in mass media. This visual study, which compares Baroque Art to Neo-baroque mass media production, aims to notice similarities and differences and watch that there are cultural parameters that have settled in the collective ideals about the concept of poverty. Moreover, the paper proceeds to an analysis of media representation of social exclusion and its interpretation within popular culture.
\end{abstract}

Keywords: television, philosophy of communication, poverty, popular culture.

Gil-González, J.C., Contreras-Medina, F.R. (2014): A critical study of the representation of poverty on TV. Arte, Individuo y Sociedad, 26(3) 437-451

Sumario: 1. Introducción: el espectáculo de la pobreza, 2. Un análisis crítico entre el arte y la ciencia de la comunicación, 3. Mostrando fragmentos de realidad: hacia una conciencia social televisiva, 4. Los medios de comunicación en la posmodernidad: la industrialización de la pobreza, 5. La presencia de la pobreza en los medios de comunicación. 6. Conclusiones. Referencias. 


\section{Introducción: el espectáculo de la pobreza}

Tras una serie de emisiones de televisión cuyo hilo conductor era la marginación social, y concretamente, la pobreza, comenzamos a plantearnos cuál sería la propedéutica idónea para su estudio. Fue la creencia de que el objeto de investigación debía eludir el fuerte positivismo que suele arrastrar las ciencias sociales en la actualidad, la que nos impulsó a combinar la hermenéutica con la teoría del arte junto con un análisis cultural del discurso televisivo. La observación y la posterior reflexión, entendida como estrategia crítica, analítica y alejada de la perspectiva empírica, puede considerarse la primera aportación de este artículo.

Lo primero que hemos de aclarar es saber qué entendemos por pobreza. Una primera aproximación a su conocimiento bien podría venir desde la economía que la definiría como la situación en la que se encuentran aquellas personas que no son capaces de cubrir sus necesidades básicas (Rodríguez-Ferreras, 2002). No obstante, como ha expuesto Vu (2010: 989-1010), "la interdisciplinariedad de las ciencias sociales ha ofrecido distintas perspectivas desde la psicología, la sociología, las ciencias políticas y la antropología. Estas disciplinas han focalizado la investigación de la pobreza en otras direcciones distintas a la economía, trabajando sobre la cultura de la soledad, la globalización, el materialismo, la estratificación social, la segregación, el racismo, las disfunciones del mercado, las barreras estructurales e institucionales e incluso incluyendo perspectivas feministas".

En este sentido es fundamental también reconocer la labor de concienciación y visibilidad que llevan a cabo los medios de comunicación en relación con los considerados invisibles en nuestra sociedad. Por ello, nuestra reflexión no debe entenderse como un rechazo a la actividad periodística televisiva que se centra en la marginación social, muy al contrario, pretendemos estudiar su apreciable labor y aportar elementos analíticos para una discusión constructiva.

Este artículo no es crítico con la práctica periodística, sino con la naturaleza del medio donde se desarrolla la visibilidad. Siendo conscientes de las limitaciones discursivas en el tratamiento informativo de cualquier fenómeno, el centro neurálgico de nuestra investigación es el medio de expresión de la situación de pobreza. "El motivo también ha sido expuesto por otros científicos como los antropólogos Arjun Appadurai o Clifford Geertz., (Green, 2006: 1108-1129). Se trata del poder que tienen las tecnologías de la representación de agudizar o reducir la gravedad de este asunto, la misma idea pública de pobreza y la valoración que hacemos de las distintas historias cotidianas que implican también las causas por las que las personas han llegado a ese estado de pobreza".

Este punto de partida explica que en la elección metodológica hayamos optado por la hermenéutica para la crítica del discurso televisivo. También hemos implicado en el estudio algunas directrices de la teoría del arte para comprender el proceso creativo del discurso. Finalmente, hemos trabajado con el análisis semiótico del discurso televisivo teniendo en cuenta el entramado cultural en el que se encuentra inmerso, y del cual, es imposible aislarlo. La forma de asumir esta reflexión no es completamente inédita. Ha sido Foucault (2010: 40) quien nos ha inspirado esta visión del objeto de estudio, pues él sostiene que "tal vez sea tiempo de estudiar los discursos ya no solamente en su valor expresivo o sus transformaciones formales, 
sino en las modalidades de su existencia: los modos de circulación, de valoración, de atribución, de apropiación de los discursos varían con cada cultura y se modifican en el interior de cada una; la manera en que se articulan sobre relaciones sociales me parece que se descifra de modo más directo en el juego de la función-autor y en sus modificaciones antes que en los temas o los conceptos que ponen en práctica".

Esta reflexión de Foucault ha influido en nuestra investigación para entender cómo el discurso televisivo se independiza del periodista y adquiere, a su vez, otros valores semánticos a partir de su exhibición mediática. Precisamente, es a partir de ese momento cuando comienza nuestro estudio pues nos fijaremos en cómo funciona el mensaje al entrar en el entramado cultural y en la interacción social.

Finalmente, queremos puntualizar otro aspecto importante. No es arriesgado decir que casi toda la investigación social surge de una situación que el investigador considera desequilibrada en algún aspecto. En este sentido, la hipótesis parte de la capacidad de representación e información que ofrece la televisión de las escenas de la vida cotidiana de los marginados sociales. El arte ha tenido esta facultad desde el siglo XVI cuando maestros como Pieter Bruegel el Viejo (1525?-1569) trabajaban en escenas de campesinos y de la vida rústica (Gombrich, 2012: 381-382) y su continuación en este género en la obra del artista Jan Steen (1626-1679) con escenas de la vida popular (Gombrich, 2012: 428). También sirve como referencia artística concreta, el esfuerzo de Rembrandt van Rijn en el aguafuerte titulado Cristo predicando (1652) en el que aparecen pobres y hambrientos desde una representación que busca la franqueza y la autenticidad (Gombrich, 2012: 427). En nuestro artículo, la proposición que someteremos a examen es si la representación televisiva del estado de la pobreza termina con la reificación del fenómeno, sus personajes y sus historias. Es decir, si la denuncia social de la pobreza en el medio televisivo acaba reduciendo su humanidad a la condición de cosa. Nos dirigimos a comprender que, del mismo modo que el arte se planteó la representación de proximidad a la realidad y a la verdad, logrando con éxito esta comunicación con el público que admiraba en aquellos tiempos estas obras, si es posible lo mismo desde la televisión con su audiencia.

Esta hipótesis tiene en cuenta que un medio de comunicación funciona bajo la lógica mercantil del máximo beneficio que puede predicarse de cualquier empresa. Además el discurso televisivo busca la espectacularidad con la finalidad de captar amplias audiencias a las que se les vende la novedad informativa. Y finalmente, tenemos en cuenta que la televisión se dirige a un espectador pasivo colmado por la experiencia vicaria. Cebrián Herreros (2004: 176) se muestra muy cercano a nuestra reflexión y señala que "la competitividad ha llevado a la lucha por ver qué canal ofrece más sangre, más cuerpos destrozados y con la mayor aproximación física de los planos detalles. Esto provoca impactos sensoriales y emocionales, pero no ayuda a comprender la complejidad de los hechos. Se falta al respeto y a la dignidad de las personas muertas y a los sentimientos de las familias. La información no gana nada salvo en el aspecto comercial de arañar alguna décima en el share al canal rival por el morbo de las imágenes".

Por otro lado, la solidaridad mediática dista de la acción solidaria por su condición ontológica: no es lo mismo conocer para hacer el bien que querer hacer el bien. 
La televisión establece en su discurso una separación nítida entre la dimensión simbólica y la realidad social, y si bien el conocimiento de la realidad social obedece a una representación simbólica hecha por el medio, el discurso televisivo no tiene repercusión sobre el conjunto de la sociedad, como sucede con las acciones jurídicas o políticas.

Por todo ello, el artículo ofrece una reflexión sobre la idoneidad de la televisión para la concienciación y sensibilización frente a determinados contenidos sociales, centrándose en el estudio de las debilidades creativas de dicho medio y en la complejidad de la observación del aislamiento, la soledad y la estigmatización social de la persona inmersa en la pobreza, como se deriva del estudio de Stewart, Marwarimba, Reutter, Veenstra, Raphael y Love (2009). Y esos aspectos los compararemos con las creaciones artísticas que se han centrado principalmente en la pobreza. Sabemos que desde la primera mitad del siglo $\mathrm{XV}$, los artistas buscaban la familiaridad de las escenas representadas con la finalidad de acercarse a sus espectadores. Citemos por ejemplo La pesca milagrosa (1444) del artista Konrad Witz, una representación del encuentro entre San Pedro y Jesucristo de la que Gombrich (2010: 245) dice:

Es ésta quizá la primera representación exacta, el primer retrato de un paisaje auténtico que jamás se haya intentado. Sobre este lago, Witz pintó pescadores reales; no los sublimados apóstoles de obras antiguas, sino toscos hombres de pueblo, ocupados con sus aparejos de pesca y que procuraban desmañadamente que la barca no volcara. San Pedro que está en el agua, parece desvalido, y seguramente fue así como se sintió. Sólo el Cristo se mantiene de pie sosegado y firmemente. Su sólida figura recuerda las del gran fresco de Masaccio. Debió ser muy emocionante para los fieles de Ginebra mirar el altar por primera vez y ver que los apóstoles eran hombres como ellos, pescando en su propio lago, así como al Cristo resucitado apareciéndoles milagrosamente en sus familiares orillas para ayudarles y consolarles.

Pretendemos mostrar, tal como se deriva de esta larga cita, si en comparación con el arte, el periodismo televisivo induce a la simplicidad en la exposición de los contenidos, sin opción de potenciar otros aspectos más nobles y sin ofrecer la posibilidad de abrir otras significaciones.

\section{Un análisis crítico entre el arte y la ciencia de la comunicación}

Sobre la televisión se vienen desarrollando diversas corrientes teóricas próximas a nuestro objeto de estudio, entre las que sobresale el análisis cultural (Cf. Casetti y Chio, 1999: 293-321). Dentro de los relatos de la mediación televisiva, este artículo aporta argumentaciones retóricas, más que demostraciones lógicas, pues, no hemos construido un discurso analítico basado en los procesos positivistas de la cuantificación, sino que hemos apostado por otros lugares de réplica donde la transposición de puntos de vista permita la fundación de nuevos argumentos críticos.

Para el estudio hemos asumido la vinculación entre las teorías del arte y las teorías sociales que ofrecen una nueva visión del fenómeno de la comunicación, de sus procesos y de sus prácticas. Nuestro enfoque se basa en la significación que se deriva de la forma y en la significación que se deriva del contenido. 
Para la acotación epistémica de la investigación hemos asumido la comparación entre la representación artística barroca y la mediación televisiva neobarroca que expone la marginación sufrida por las personas invisibles de nuestras ciudades. Hemos adoptado la semiótica posestructuralista para mirar el relato de la pobreza, pero más importante ha sido considerar la herencia cultural que conforma la comunidad de interpretantes que supone la audiencia. No existe relato sin su tejido de voces subyacentes (Cf. Wodak y Meyer, 2003: 93) que afirman las ideologías de los discursos mediáticos.

El artículo es un estudio crítico que acepta postulados de la filosofía posmoderna, por ejemplo, la depreciación de los grandes metarrelatos, y de otras fuentes previas, como es el pensamiento de Walter Benjamin. En nuestro caso, lo que hemos pretendido es adoptar con naturalidad la representación televisiva en la cultura popular contemporánea. La crítica posmoderna se centra, más que en los efectos sociales, en la elucidación inferencial de las lecturas de los relatos televisivos, en la solución de los problemas interpretativos e, incluso, en los modos de construcción de los significados. Además, pensando en nuestro objeto de estudio, coincidimos plenamente con lo que afirma Popelka Sosa (2009: 97): "El desarrollo de nuevas manifestaciones artísticas permite la alianza con el pensamiento posmoderno en la tarea de hacer un discurso combativo en el que aparecen unidos la política, la estética, la economía y la ética. Todo ello reflejo de una multiplicidad de tendencias existentes en la sociedad de fin de siglo".

Finalmente, nos queda la última crítica a estos contenidos audiovisuales basados en la reflexión teórica. Apoyándonos en parte en la lección aprendida de Michel Foucault (Cf. Foucault 1999) en Esto no es una pipa, cabe pensar en el siguiente razonamiento. Los programas de televisión, por la relación entre el texto oral y las imágenes, ¿no hacen decir a las imágenes aquello que dice el texto, deformando el auténtico sentido del hecho? Advirtamos que la pobreza es un estado o circunstancia, pero que no es inherente a la naturaleza humana como muestra el discurso. Sin embargo, los personajes televisivos son las figuras de la pobreza. No son pobres los que vemos, sino personas que un tiempo determinado viven en una situación de pobreza. La televisión ya los ha transformado en figuras/objetos, aplicando las similitudes y semejanzas que acercan la figura y el texto.

\section{Mostrando fragmentos de realidad: hacia una conciencia social televisiva}

La pobreza, la drogadicción, la delincuencia, el alcoholismo son los objetivos principales de estos programas. En estos tiempos en los que la historia del hombre se escribe con recortes de periódicos o fragmentos de cine, radio y televisión... se consolida la noción del discurso mediático entendido como una memoria externa construida por la denuncia social, cultural o política. Esta denuncia se basa en el poder que ostentan los medios para otorgar visibilidad a las personas o las cosas en el espacio público. De este poder institucional, que conforma gran parte de la opinión pública, también se deriva su obligación moral. En nuestro caso, la obligación moral de la televisión consiste en exponer a la audiencia la vida de los marginados dentro de sus respectivos contextos.

En no pocas ocasiones, la memoria social de una determinada situación de 
pobreza se transforma en conciencia social. En esta transformación existe un cierto desprecio mediático a la tradición local. La denuncia televisiva niega la conciencia individual y la función de los lazos sociales o familiares que la experiencia individual ha ido entretejiendo. Es como si el medio remediara la insensibilidad social frente a la marginación y la miseria. Frente a este estado, el medio trabaja, en su discurso, la denuncia social y la reconstrucción de la conciencia colectiva. De este modo, la televisión se hace instructiva, es decir, nos dice /qué debemos hacer/y /en qué debemos pensar/.

Pese a la voluntad de los medios y de sus profesionales por motivar al espectador pasivo que contempla la televisión o lee la prensa, el mensaje casi siempre acaba en la confirmación de las creencias de los destinatarios y potencia su dejadez debido a que acepta como rutinaria una situación excepcional. Tampoco la certeza del mensaje provoca más reacción social cuando se descubre la química de la argumentación a partir de la modalidad semiótica /hacer creer/ y del contrato de veridicción en el que el sujeto de la enunciación trata de producir solo el efecto de sentido 'verdad' en el discurso (Cf. Greimas, 1989: 119-131). Sencillamente, estamos saturados de verdades mediáticas construidas que devienen en evidentes; y no deseamos que nadie nos pida más a través del discurso moral dirigido a nuestras conciencias, hastiadas ya de tanta exigencia solidaria. Semióticamente, esto último obedecería a las modalidades / deber-hacer/y de /saber-hacer/, de cuya confrontación surgen los códigos sociales de carácter normativo (Cf. Greimas, 1989: 104-105).

No obstante, e introduciendo ya un punto de inflexión en nuestra exposición, cabe preguntarse: ¿por qué los medios tienen este empeño de introducir la miseria, la pobreza o la marginación en su discurso, cuando el resto de su actividad está orientada a la satisfacción del espectador, y sobre todo, a la búsqueda de su entretenimiento? ¿Por qué nos imponen compartir la desgracia de los afligidos y de los marginados?

Si volvemos a la función edificadora de los medios en la construcción de una determinada identidad, nos percatamos de que la televisión es un mediador que construye, con sus recursos técnicos y criterios, tanto la identidad de la pobreza y la miseria como la identidad de la marginación. Pese a este buen comienzo, las exigencias lógicas de una empresa, las limitaciones discursivas o argumentativas de las técnicas de reproducción, la falta de profundización en el proceso de documentación, la ausencia de conocimiento íntegro del fenómeno y las condiciones impuestas por el discurso especular del medio, acaban deformando las primeras intenciones.

La pobreza aporta al discurso televisivo imágenes nuevas y espectaculares de lugares, personas y entornos sociales sórdidos y desconocidos que alteran el estado emocional del espectador provocando generalmente sensaciones de angustia, dolor, compasión, humanidad... Es decir, ese mensaje va dirigido al ethos y al pathos de la audiencia, con formato de denuncia social, a través del modelo de reality show o telerrealidad. La pobreza y la miseria se han convertido en un marcador de realidad en el discurso televisivo, puesto que la autenticidad de esos duros mensajes connota la verdad sobre aquello que no nos es ajeno ni distante. La pobreza, que también produce miedo, tensión, fricción con la cotidianidad, es un buen recurso retórico, incluso para convencer de alguna verdad manipulada con intenciones políticas.

La complejidad humana de la pobreza no es apta para la explicación mediática 
del fenómeno. En el relato de los medios, los actantes de la pobreza no son sólo los mismos pobres; pues para comprender su situación hemos de reconocer el papel primordial asignado a los héroes. Tanto los personajes de ficción como Robin Hood, con sus múltiples versiones literarias (Walter Scott, Howard Pyle, Alejandro Dumas) y cinematográficas (Percy Stow, Robert Frazer, William Keighley y Michael Curtiz, Kevin Costner, Ridley Scott) como los personajes reales convertidos en ficción por la industria audiovisual como Mahatma Ghandi, se han convertido en iconos ejemplares por la defensa de los ideales de igualdad y humanidad.

Los líderes políticos y sindicales, los organizadores de acciones reivindicativas e incluso los responsables de las ONGs, funcionan, a su modo, como estos personajes moralistas del siglo pasado, principalmente en las noticias sobre la cultura popular contemporánea. Ya tenemos nuestros roles temáticos; a saber, los héroes contemporáneos, el objeto de deseo y nuestros oponentes en la narración. También contamos con la trama del relato: los pobres en el mundo; los moralistas descubriendo la miseria; y el capitalismo exacerbado representando los intereses egoístas. Éstos son los elementos del universo narrativo.

De este modo, curiosamente, se invierte el sentido de la información. Es decir, de su modalidad actualizante /saber ser/ pasamos a una modalidad virtualizante / deber ser/ o sea, de la honestidad profesional a la subjetividad más interesada (Cf. Greimas, 1989: 114-115). Como en el mito, el cuento o la novela, la pobreza es un recurso narrativo en el relato informativo que muestra al espectador una historia de supervivencia. Con lo cual, para la narración audiovisual e incluso para el discurso social, esta forma de actuar constituye una táctica discursiva manipuladora. La pobreza se transforma en un símbolo contemporáneo que abandera los discursos éticos e ideológicos como ya ocurriera durante el Barroco español con el idealismo y el naturalismo popular, como sostiene Campoy (1983: 22):

La España del siglo XVII se caracterizó por la violenta oposición entre el idealismo más acendrado, que la condujo a la mística y a la ascética, y el naturalismo popular. Otros pintores expresaron esa España: El Greco, Zurbarán, Ribera, Murillo. Velázquez, que rechazó con la misma fuerza los excesos de pasión y el racionalismo abstracto, pintó otra España, quizá la más auténtica por ser la más profunda, la menos España porque es una expresión universal.

¿Podríamos asumir esta dicotomía en la era neobarroca de la televisión? Mientras el periodismo ético podría aproximarse a la situación de pobreza, el discurso político televisivo la emplea para la obtención de determinados fines políticos. La humanidad se define de este modo a través de la ayuda al desvalido (periodismo), al débil (política) y al necesitado (religión). La información nace de la denuncia (periodismo), del compromiso (política) y de la caridad (religión). Y finalmente, la pobreza abre una correspondencia simbiótica entre la emoción de las sensaciones (periodismo), la inteligencia controladora (política) y los sentimientos de hermandad (religión). Esta tríada ya funcionaba en el Barroco, según Campoy (1983: 21-22), en la que la pintura presentaba estilos contrastados al enfrentarse a lo popular: 
Velázquez pinta una vida doméstica que parece prolongar la que Quevedo ya daba por perdida:

"Carnero y vaca fue principio y cabo;

y con rojos pimientos, y ajos duros

tan bien como el señor comió el esclavo...

el rostro macilento, el cuerpo flaco,

eran recuerdo del trabajo honroso;

y honra y provecho andaban en un saco..."

En esta primera obra sevillana vemos ya un Velázquez aislado y aislador, tranquilamente marginado de las pasiones de su tiempo. No se compromete con aquella Sevilla que limosnea empiojada en los cuadros de Murillo; entonces y después, cuando haya de ocuparse de los hombres lo hará con lejanía, no sabemos si idealizándolos hasta lo mitológico o si vulgarizando la mitología hasta extremos de borrachera popular o fragua de fragüeros rasos.

\section{Los medios de comunicación en la posmodernidad: la industrialización de la pobreza}

Los medios de comunicación podrían ser acusados de comercializar con una información basada en la estética de lo mísero. Frente al brillo y la puesta en escena de los grandes espectáculos televisivos, la pobreza representa la estética de lo sucio, lo oscuro, lo abominable, lo repulsivo y lo feo. La pobreza es la antítesis de la belleza del espectáculo televisivo que aparece en los espacios del late night show. Si a todo ello le sumamos lo grotesco, desde la estética, y lo compasivo, desde lo ético, obtenemos una fórmula nueva para los guiones mediáticos. De este modo, la pobreza se convierte en una fuente de creación industrial de historias que podemos escribir, grabar, editar y emitir que tienen el añadido de la verosimilitud.

Tanta exhibición de la indigencia humana nos lleva a pensar si la visibilidad necesaria de los problemas sociales por parte de la opinión pública no está sobrepasando los límites de lo ético. Esta duda razonable se produce porque la programación de los diferentes canales estandariza ese tipo de contenidos y provoca la asimilación pasiva en los espectadores, los cuales, asumen como un contenido más, sin diferencia aparente con el resto, las calamidades de sus semejantes.

No queremos decir que la presencia de la situación desesperada de los desvalidos en los medios de comunicación no sea realmente necesaria. Muy al contrario, sostenemos que la opinión pública debe ofrecer esa cara de la realidad social a su audiencia. Pero esta obligación informativa de la televisión respecto de la marginación social, nos inquieta porque su tratamiento puede provocar consecuencias sociales poco afortunadas.

Si bien es verdad que la narración periodística recompone la percepción del mundo, ésta debe hacerlo a partir de un patrimonio cultural común que, yendo incluso más allá del propio proceso comunicativo, nos permita absorber la realidad. Es lo mismo que sostenía Foucault (2010) cuando pensaba que el autor se percataba de que, antes de nacer su obra, ésta ya estaba inmersa en un complejo entramado cultural que le iba a condicionar su texto. Ahora bien, como el entramado cultural varía en el espacio, con el paso del tiempo y con la percepción social o individual, es imposible que dicho tejido cultural aporte experiencias que hermane a los hombres o a las generaciones. 
Sin embargo, la información televisiva stricto sensu no forma parte de la experiencia humana, si esta es entendida como el conocimiento heredado de la convivencia de nuestras generaciones transmitido a través de la cultura popular (del mito, el cuento, el relato oral). Desde esta perspectiva, la televisión es siempre normativa para encontrar algo, nos indica qué debemos hacer. Todo lo contrario a la experiencia que "es algo que uno mismo descubre, pasando el trance a que se ve expuesto a lo largo del proceso de la experiencia, sugerida por la indicación sabia del otro. Gracias a este proceso, es experiencia y experiencia de vida. En la medida en que pasa por el trance, transforma la vida, comunica la vida" (Amengual, Cabot y Vermal, 2008: 42).

La televisión sólo ofrece una experiencia mediada, es decir, un simulacro de experiencia y no experiencia propiamente dicha. Para ello, recurre a la simplificación del relato, estrategia que obedece más a requerimientos del medio técnico, de la tecnología de la comunicación, que a las condiciones del desarrollo de la cultura popular. Ésta última no sólo comunica la experiencia, sino que además retroalimenta dicho proceso, puesto que enriquece el sustrato trascendental que posibilita que tengamos experiencias y que podamos expresarlas y transmitirlas.

La noticia televisiva recurre continuamente a la ficción fílmica ya que permite la necesaria reducción del tiempo. Para conseguir dicho efecto utiliza como técnicas narrativas, los estereotipos sociales en la descripción de los personajes y la elipsis en el montaje. Estas estrategias permiten encajar el relato en su espacio de emisión, constatando que el medio no tiene por qué ajustarse a la explicación del fenómeno. En resumen, a nuestro juicio, el tiempo de emisión, sometido a la lógica de los requisitos de una programación diaria, reduce excesivamente la narración de la pobreza impidiendo construir una experiencia sobre la pobreza.

Con la finalidad de que los espectadores puedan asimilar el sentido de la noticia, los programas de televisión dedicados a la marginación social abusan de los planos de suburbios en los que resaltan las casas abandonadas, los estercoleros, los contenedores de basura, el tráfico de sustancias ilícitas, los mercadillos ilegales... El recurso que complementa esas imágenes lo conforman las declaraciones, también en ingentes cantidades, de vagabundos, inmigrantes ilegales, drogadictos, alcohólicos, prostitutas, jugadores, parados, enfermos mentales... Además para mostrar este mundo con atracción especular, las cámaras se han hecho más pequeñas y ágiles facilitando que los reporteros recojan imágenes inéditas de los indigentes. De esta forma, se sigue ofreciendo historias incompletas, pues sólo vemos la fuerza sensorial de la reproducción técnica. Los personajes no cuentan una historia a la cámara, sólo se exponen como objetos en un escaparate.

También constatamos que la narración no obedece a la lógica interna de los relatos que provienen de la cultura popular (Cf. Thompson, 2000), muy al contrario, en algunas ocasiones esa cultura popular queda ridiculizada al resaltarse la fealdad de su contexto. Se podría decir que muchos errores de lectura de estos contenidos proceden de un intento de instaurar una coherencia superficial, para dar una cierta coherencia discursiva, que suprime, lo que en apariencia, ya se ha dicho.

Otro de los recursos discursivos de estos programas televisivos reside en mezclar la mendicidad, el tráfico de drogas, la prostitución y la supervivencia con la tradición, 
el espectáculo popular, el comercio ambulante o el arte popular. Si nos fijamos con detenimiento son dos realidades que no se corresponden. La cultura popular guarda diferencias sustanciales con las subculturas urbanas modernas. Pese a esta incoherencia discursiva, se suele emplear la iconografía popular como medio de expresión de una subcultura urbana común a todos los lugares. La cultura popular viaja en un ir y venir entre el campo y la ciudad, mientras que las culturas urbanas son exclusivamente de las ciudades y las subculturas urbanas de sus zonas periféricas o zonas aisladas.

Por eso, inteligentemente, Walter Benjamin establecía, según Martín Kohan (2007: 97-98) diferencias entre los mendigos de las ciudades de París, Nápoles, Moscú o Berlín. Observaba cómo los mendigos de París se emparentaban con el poeta Baudelaire. En Nápoles, la marginalidad se veía en todas las calles de la ciudad; según Benjamin, la miseria ascendía a la superficie. Por el contrario en Berlín, la miseria se veía exótica, ya que sólo correspondía a zonas apartadas de la ciudad. Y finalmente, en Moscú, los pobres revelaban más vitalidad debido al alcohol y a su agresiva abundancia (Martín Kohan, 2007: 97-98). Aunque la vida en las ciudades modernas ha cambiado sustancialmente desde las observaciones de Benjamin, la mirada cultural sobre la marginalidad sigue utilizando los mismos patrones con los que trabajaba el pensador alemán.

\section{La presencia de la pobreza en los medios de comunicación}

A pesar de que el motivo de la emisión de estos programas es la denuncia social de la marginalidad, la televisión no está ligada a una praxis de resistencia y de solidaridad ya que sólo consigue ofrecer un simulacro de lo que ocurre en la realidad. No obstante, el discurso de la información parece surgir de una lucha contra el tótem del consumo y del capitalismo, y busca colocarse al lado de las víctimas. El discurso plantea momentos de verdad revestidos de crítica y ética en el acto de decir mediante el uso de la retórica y la pragmática televisiva. Es decir, el espíritu crítico que mueve la imagen emitida nos hace pensar en las posibles intenciones éticas de la empresa informativa y de su relación con las instituciones sociales.

Sería injusto obviar un matiz. Es cierto que, en algunos casos, estos programas han conseguido emocionar, sensibilizar y concienciar a la audiencia a través de lo jamás mostrado. Sin embargo, en pocas ocasiones, la audiencia se ha movilizado por la interpretación ofrecida de estas historias. Quizá debido a su repetición, ya no sorprende la existencia de la miseria, ni de la pobreza, ni de la marginalidad y ni de la autodestrucción de las personas. Dicha normalidad no remueve la conciencia idealista de la audiencia. La televisión impone todo como absoluto siendo finita su presencia en el fenómeno. La praxis solidaria aparece unida a la praxis de la resistencia. En ocasiones, las historias periodísticas cultivan la seducción proclamándose la voz interna de nuestra conciencia. En estos casos, la televisión acentúa el dogma imposible, una falsa fe optimista, que se desvanece con el botón de apagado de nuestro televisor.

El arte, por otro lado, siempre ha plasmado la marginación social en sus manifestaciones. En determinadas civilizaciones, como en Egipto, los propios monumentos han servido para testimoniar la presencia de una población de esclavos, como se ve en el caso de las pirámides. En el imperio romano, existían representaciones 
de los pobres y de los esclavos en sus mosaicos, cerámicas y otros objetos. En la Edad Media y el Renacimiento, los pobres solían aparecer como analogía del siervo de Dios.

Fue concretamente durante el siglo XVII cuando la pobreza se convirtió en un tema cultivado y vinculado a la cultura popular. En la pintura barroca, como ha defendido Campoy (1982: 10), fue Murillo uno de los precursores del arte costumbrista y popular que no siempre representó las bondades de la vida:

En la dureza de nuestra existencia actual, los cuadros de Murillo parecen una impostura, dice Valeriano Bozal, que olvida, porque le conviene, al Murillo de las escenas miserables, al pintor de los pobres, que hoy podrían llamarse proletarios, con lo que se rechaza toda la pintura europea, tan opulenta y llena de apacible hermosura, y puede salvarse esa otra pintura que narra desdichas tremendas, como las del hambre en Madrid, del davidiano Aparicio, precursor del realismo socialista. Los menos afortunados, en cambio, perciben la belleza y la paz que la existencia niega.

Esta relación entre la pintura y lo popular podría identificarse con la actual vinculación en el tratamiento de la pobreza por parte del periodismo televisivo. El periodismo televisivo juega con la innovación audiovisual sobre temas populares. En este punto se requiere el interesante concepto de innovación artística ofrecido por Groys (2005: 19):

La innovación no consiste en que comparezca algo que estaba escondido, sino en transmutar el valor de lo visto y conocido desde siempre... La transmutación de los valores es la forma general de la innovación: en ese acontecimiento, lo verdadero y lo distinguido, que tiene vigencia como valioso, resulta devaluado, y se revaloriza lo que antes se consideraba carente de valor, profano, extraño, primitivo o vulgar. Como transmutación de valores, la innovación es, pues, un proceso económico.

La televisión trata de acomodar el valor material del hecho en el valor ideal de la información. Otorga la categoría de significante a la noticia que, aquí y ahora (deixis), significa que la situación de pobreza es algo novedoso. Para nuestra reflexión, la pobreza, al ser un problema social conocido, por antiguo y repetido, requiere de un significante que cautive a la audiencia, para lo cual, es necesario la puesta en práctica de técnicas de ficción, tanto escritas como audiovisuales, y de técnicas de representación. El dominio del uso de las estructuras racionales y lingüísticas por parte del periodista permitirá simultáneamente que aparezcan varios modos de realización.

De este proceso creativo surge la representación de un modelo discursivo ideológico. En su unidad total cuenta con otros efectos psicológicos como la catarsis del espectador, enmarcada en la precariedad de la vida moderna y su significación social (aislamiento, invisibilidad, discriminación), y el entramado cultural en el que se inserta. La suma de todos los aspectos apuntados acabará en una idealización radical de la pobreza hasta el punto de atemorizar, avergonzar sin pretender reactivar al espectador, como hizo el arte en el pasado.

La televisión es una tecnología de la reproducción de la experiencia, más popular que la pintura y la escultura. No obstante, la pintura posee una pragmática distinta, ya 
que, tanto la producción como la contemplación exigen condiciones muy diferentes a las del espectador. La pintura es una experiencia espiritual, mientras que la televisión, salvo raras excepciones, es puro espectáculo. Para el caso similar de la narración, Benjamin (2009: 48) sostiene que "la información tiene interés tan sólo en el breve instante en que es nueva. [...]. Por el contrario, la narración jamás se entrega, sino que concentra sus fuerzas, y mucho tiempo después aún sigue siendo capaz de desplegarse".

La televisión, hasta hora, sólo ha conseguido construir simulacros. La experiencia basada en el simulacro mediático se agota en un espectáculo grotesco de máscaras y monstruos que deforman la tradición popular a la que necesita para su originalidad. Sobre esto Scruton (2001: 56) apunta que "sin tradición no puede haber novedad, porque ésta solo puede advertirse en contraste con la propia tradición. Tradición y originalidad son dos componentes de un solo proceso a través del cual el individuo se da a conocer mediante su pertenencia al grupo histórico".

La narración audiovisual de la pobreza ofrece múltiples interpretaciones y, en algunas ocasiones, ha servido para otros fines distintos al de la concienciación social. Sin embargo, pensamos que la creatividad mediática debería sobrepasar el simulacro para alcanzar la contemplación: debería conseguir que el espectador experimentase la pobreza. La televisión debería abrir un tiempo de meditación y de abstracción, como cuando miramos los enfermos pobres de Murillo.

El arte ha empleado también la pobreza en las imágenes religiosas para otorgar una áurea de santidad a sus personajes como son los ejemplos de las figuras de Santo Tomás de Villanueva (1678) o de Santa Isabel de Hungría curando a los tiñosos (1667-1670), ambos obras pintadas por Murillo. El arte Barroco expuso en numerosas ocasiones la pobreza, y lo hizo con más intención que mostrar la superficie de la apariencia.

En la era neobarroca (Cf. Calabrese, 1994), no podemos resistirnos a la comparación hermenéutica entre la pintura de Velázquez titulada Vieja friendo huevo (1618) y la insistencia televisiva de insertar planos de familias comiendo tortillas en las playas o en los campos, dentro de espacios tan similarmente reducidos como es la sombra del parasol o el hueco cómodo que produce accidentalmente el paisaje campestre. Pese a la semejanza formal en este ejemplo, sería superficial suponer que significan lo mismo las dos imágenes realizadas en momentos y contextos distintos. Simplemente si consideramos en las circunstancias en las que trabajan los creadores ya tenemos una diferencia radical. No debemos olvidar la autonomía del artista y la dependencia del creador mediático en la lucha por las audiencias. De acuerdo a lo que sostiene Aguilar Alonso (2010:107), en el arte todavía habita la resistencia: "autonomía artística y libertad se identifican, ya que es el acto creativo del hombre verdaderamente libre el que permite que una obra conserve su autonomía, sus propias leyes, a pesar del nuevo orden mundial y su potencial destructivo".

Velázquez también pinta El aguador de Sevilla (1620) y El almuerzo (1617-1618), imágenes muy próximas a las que la televisión muestra de las escenas diarias. De acuerdo con Campoy (1982: 19) El pintor repasa la belleza de la etiqueta cortesana de la monarquía de Felipe IV, y curiosamente, también es amable con la fealdad de los borrachos, los enanos, Esopos, Menipos y Pablillos: 
Otros pintores han pintado enanos reales como quien pinta perritos tiñosos. Velázquez pinta hombres de pequeña estatura, pero hombres. Carece su musa de morbosidad-dice José María Salaverría-, de comentario enfermizo. Elude toda decadencia y complicación patológica y, más bien que del siglo XVII, necesitaba haber sido Velázquez un hombre del Renacimiento, súbdito de Carlos Vy compañero de los escritores varoniles, sanos, fuertes, como Hurtado de Mendoza, Herrera, Granada y el propio Cervantes. Es un alma que no se queja, que no decae, que no tiene amargura ni pesimismo. Sus Menipos, Pablillos, Esopos, sus enanos y sus borrachos, tienen una monstruosidad saludable, una alegría franca y normal... ' y Salaverría lo llama 'pintor caballeresco'.

El barroco de Velázquez o de Murillo tiene mucho de televisión actual, sobre todo, en su empeño de representar lo popular. Si bien, ambos discursos coinciden en que sus protagonistas formen parten del pueblo, la aceptación pública es distinta. Mientras que en el Barroco la pintura de Murillo vincula el arte a lo popular a través de determinadas obras, en la era de la comunicación, la exposición de lo popular se ha convertido en un relato recurrente y muy adecuado para complementar otros discursos gracias a la labor desempeñada por los medios, principalmente, la televisión, cuya difusión y consumo son masivos.

En la concepción del individuo, desde el Barroco a la Modernidad, la pobreza era una prueba de la existencia de los vaivenes y avatares de la vida del ser humano que admitía, con dignidad, el orden natural o el destino de la vida. A partir de las primeras formulaciones materialistas, la pobreza se ha metamorfoseado en objeto de transformación para las ciencias sociales (sociología, psicología, antropología, economía, derecho). La pobreza ya no es condición circunstancial del individuo sino que es un problema de la colectividad. Diógenes deja de ser un pobre filósofo que vivía en un tonel y se convertido en la denominación de una enfermedad mental. La pobreza se hace indigna y es tratada como un padecimiento psicológico por las sociedades modernas.

\section{Conclusiones}

No es cinismo lo que reconocemos en la actitud de los pobres que salen en los medios. Ellos hablan de injusticias nacidas de la enemistad social. Los pobres son, en ocasiones, injustamente maltratados y su dignidad ofendida. Su entorno es temible y desgraciado. Viven rodeados de individuos que los ignoran y que, a veces, los convierten en objetos causantes de la delincuencia e inseguridad de nuestras ciudades.

Visto desde esta perspectiva, este mensaje se transforma en argumentario del discurso político, es decir, se esgrime como un medio para construir la confianza popular en el mensaje político. La consecuencia es clara: para construir la confianza y el orden social, la política debe contener y marcar los límites en los que se pueden mover los esquinados del propio sistema social.

Durante el Barroco, el arte estaba al servicio propagandístico del Monarca. La arquitectura, la pintura, la escultura y la producción de los objetos artísticos representaban al poder a través de la ostentación exacerbada del lujo y de la exquisitez más refinada en las formas. La riqueza del rey y su nobleza eran la garantía de seguridad de la nación. Ahora, para la ciudadanía democrática del siglo XXI, la 
prueba del bienestar y el progreso social se cifra en la presencia o ausencia de la pobreza, que se ve reflejada en los medios.

Desde nuestra perspectiva, la televisión linda, a la vez, entre las fronteras de lo creativo y de lo destructivo. La pantalla sólo muestra el presente, y sin embargo, las historias de las vidas de nuestros personajes alcanzan su punto más dramático cuando proyectamos su existencia en el futuro.

La cámara graba el presente, pero entreabre la mirada hacia la fatalidad futura. Es decir, el drama humano se adivina virtualmente en las escasas posibilidades que poseen estas personas para salir de esa situación reproducida por los medios.

El destino de los hombres, vacuo de categoría existencial, se narra a través de personajes construidos para la ocasión. El discurso social de los medios cruza de la compasión humana a la denuncia social. La dimensión espiritual de la representación se vacía de metafísica. No queda conciencia, ni experiencia.

La televisión ya no muestra la esencia de los hechos del mundo. Ya no ofrece una historia de la vida, sino fragmentos de diversas historias que se dispersan por su discurso, el cual aprovecha la ocasión para montar un pequeño espectáculo en la pantalla. La ventana televisiva impone el destierro, el olvido y la evanescencia de la conciencia social de la audiencia.

Las interpretaciones del mundo hechas por la televisión no profundizan como sí ocurre en el arte. La televisión sacrifica la espiritualidad de la obra de arte, basada en la contemplación, por un consumo vertiginoso de planos encadenados de realidades vulgares que se consumen con rapidez, impidiendo conocer el contexto y saber el significado profundo de la situación que se ofrece.

Finalmente, la diferencia entre el discurso mediático y el discurso artístico es equiparable a la diferencia que se da entre una moral mediática y una moral arraigada en la experiencia artística. Es decir, por un lado, nos encontramos con el tono de la instrucción social o el discurso normativo, para el caso de la televisión, y por otro lado, tenemos la creación de un cosmos simbólico abierto a la libre interpretación a partir de la experiencia inagotable del arte.

\section{Referencias}

Aguilar Alonso, R. (2010). La autonomía artística frente al mercado y los medios de masas. Arte, Individuo y Sociedad 22: 95-110

Anjargolian, S. (2011). "Looking Poverty in the Eye", Journal of Poverty 15: 108111. Doi: http://dx.doi.org/10.1080/10875549.2011.540919

Amengual, G. y Vermal, J. (2008) Ruptura de la tradición, Estudios sobre Walter Benjamin y Martin Heidegger. Madrid: Trota.

Aranda Torres, C. (2009). Filosofia de la pintura en imágenes. Murcia: EDITUM.

Benjamin, W. (2009). Obras. Libro II/ vol. 2. Madrid: Abada Editores.

Calabrese, O. (1994). La era neobarroca. Madrid: Cátedra.

Campoy, A.M. (1983). Velázquez. Madrid: Cupsa.

Campoy, A.M. (1982). Bartolomé Esteban Murillo. Madrid: Cupsa.

Casetti, F. y Di Chio, F. (1999). Análisis de la televisión. Instrumentos, métodos y prácticas de investigación. Barcelona: Paidós. 
Cebrián Herreros, M. (2004). La información en televisión: obsesión mercantil y política. Barcelona: Gedisa.

Domínguez Ortiz, A. Pérez Sánchez, A. y Gallego, J. (1990). Velázquez. Ministerio de Cultura: Museo del Prado.

Foucault, M. (2010). ¿Qué es un autor?, Córdoba (Argentina): Ediciones Literarias.

Foucault, M. (1990). Esto no es una pipa. Ensayo sobre Magritte. Barcelona: Anagrama.

Gombrich, E. (2012). La Historia del Arte. London: Phaidon.

Green, M. (2007). "Representing poverty and attacking representations: Perspectives on poverty from social anthropology". Journal of Development Studies 42: 11081129. Doi: http://dx.doi.org/10.1080/00220380600884068

Greimas, A.J. (1989). Del sentido II, Ensayos semióticos. Madrid: Gredos.

Groys, B. (2005). Sobre lo nuevo. Valencia: Pretextos.

Kohan, M. (2007). Zona urbana. Ensayo de lectura sobre Walter Benjamin. Madrid: Trotta.

Popelka Sosa Sánchez, R. (2009). "La posmodernidad y su reflejo en las artes plásticas". Arte, Individuo y Sociedad 21: 89-98.

Rodríguez-Ferrera, J.C. (2002). La economía mundial y el desarrollo. Madrid: Editorial Acento.

Scruton, R.( 2001). Cultura para personas inteligentes. Barcelona: Península.

Stewart, M. Marwarimba, E. Reutter, L. Veenstra, G. Raphael, D. y Love, R. 2009. "Poverty, Sense of Belonging and Experiences of Social Isolation", Journal of Poverty 13: 173-195. Doi: http://dx.doi.org/10.1080/10875540902841762

Thompson, E.P. (2000). Costumbres en común. Barcelona: Crítica.

Wodak, R. y Meyer, M. (2003). Métodos de análisis crítico del discurso. Barcelona: Gedisa.

Vu, C.M. (2010). "The influence of Social Science Theories on the conceptualization of Poverty in Social Welfare", Journal of Human Behaviour in the Social Environment 20: 989-1010. Doi: http://dx.doi.org/10.1080/15433714.2010.4949 83 